Interactive comment on "Influence of Hydrometeorological Hazards and Sea Coast Morphodynamics onto Unique Coastal Vegetation Sites Development - Cephalanthero rubrae Fagetum on Wolin Island (the Southern Baltic Sea)" by Jacek Tylkowski et al.

\title{
Robert Kolander
}

robert.kolander@geo.uni-halle.de

Received and published: 4 September 2020

Thank you for your comprehensive answer. As I mentioned at the beginning of my review, the article deserves to be published.

Printer-friendly version

Discussion paper

Interactive comment on Nat. Hazards Earth Syst. Sci. Discuss., https://doi.org/10.5194/nhess2020-160, 2020. 